of all publications and privileges, is open to all, irrespective of nationality or astronomical qualifications.

THE Council of the Iron and Steel Institute has awarded the Connegie Gold Medal for the year 1925 to Mr. A. L. Curtis, Westmoor Laboratory, Chatteris, in recogprtion of his research work on steel moulding sand, etc.

THE Thomas Hawksley lecture of the Institution of Mechanical Engineers, on "Application of X-rays to the Study $\mathcal{Q f a r e}$ Crystalline Structure of Materials," will be delivered by Sir William Bragg, on Friday, Nov. 4, at 6 o'clock P.M.

Sir WILliam Larke, Director of the National Federation of Iron and Steel Manufacturers, has been appointed by Order of Council dated Oct. 5, 1927, to be a menoter of the Advisory Council to the Committee of tho Privy Council for Scientific and Industrial Rescarch.

Mr. F. J. BLIGHT, who since 1894 has been associated with thy well-known firm of scientific and technical pold hers, Messrs. Charles Griffin and Co., Ltd., and has been head of that house since 1899 , is retiring from that position. Many authors of scientific and technical works published by Messrs. Griffin appreciate the valuable services rendered by Mr. Blight to the production of specialised works on important aspects of modern science and industry, and trust that there are still before him further years of useful life and influence even in his retirement.
Applicatrons ar invited for the following appointments, on or before the dates mentioned :-A lecturer in building trats and a lecturer in furniture trades in the Technical College, East London, South AfricaThe Secretary, Office of the High Commissioner for the Union of South Africa, Trafalgar Square, W.C.2 (Oct. 31). A research chemist for work on plasters and other materials used for impressions and models in dentistry-The Secretary, Department of Scientific and Industrial Research, 16 Old Queen Street, S.W.I (Nov. 7). An engineer for the Sanitary Department, Buildings and Roads Branch, Government of the Punjab-The Secretary to the High Commissioner for India, General Department, 42 Grosvenor Gardens, S.W.1 (Nov. 10). A demonstrator in physiology at St. Bartholomew's Medical College-The Dean, Medical College, St. Bartholomew's Hospital, E.C.1 (Nov. 16). A chief lecturer in chemistry at the Woolwich Polytechnic-The Principal, Woolwich Polytechnic, S.E. 18. A naval architect for the Marine department of the Government of NigeriaThe Crown Agents for the Colonies, 4 Millbank, S.W.I (quoting M/6). A junior technical officer in an Admiralty experimental establishment, mainly for experiment and design in connexion with wireless and other electrical apparatus-The Secretary of the Admiralty (C.E. Branch), Whitehall, S.W.1. A principal of the Massey Agricultural College, New Zealand-The High Commissioner for New Zealand, 415 Strand, W.C.2.
Magnetic 'STORM' ANI Sysf is.-On Oct. 12, at $10 \frac{1 \mathrm{~h}}{2}$, a considerable phas disturbance commenced and lasted for on the following morning. The chief charactef sties as shown by the declination magnetograph records at Greenwich were, first, the sudden commencement; and secondly, the occurrence between $18^{\mathrm{h}}$ and $21^{\mathrm{h}}$ of three distinct waves of magnitude about $30^{\prime}, 25^{\prime}$, and $40^{\prime}$ respectively. The total range in declination throughout the disturbance was about $1^{\circ}$. A lesser disturbance, of interest on account of its sharp commencement, also took place between Oct. $9,20 \frac{1 \mathrm{~h}}{2}$ and Oct. $10,23^{\mathrm{h}}$.

At the time of the phenomena there were three groups of sunspots within a short distance of the sun's central meridian, as follows :

\begin{tabular}{|c|c|c|c|c|}
\hline & $\begin{array}{c}\text { Central Meridian } \\
\text { Passage. }\end{array}$ & Latitude. & $\begin{array}{l}\text { Area on } \\
\text { Oct. } 9 .\end{array}$ & \\
\hline & Oct. $9 \cdot 4$ & $19^{\circ} \mathrm{N}$ & 300 & Millionths of \\
\hline & Oct. $10 \cdot 6$ & $12 \mathrm{~S}$ & 500 & sun's hemi- \\
\hline & Oct. $11 \cdot 6$ & $19 \mathrm{~S}$ & 250 & sphere. \\
\hline
\end{tabular}

Both (2) and (3) were returns of large groups, conspicuous in the previous rotation, to which attention was directed in NATURE of Sept. 24, p. 456. A large area of bright faculæ surrounded these two groups of which (2) showed marked changes after Oct. 7, when new spots appeared. A connexion may reasonably be attributed between this group of spots and the magnetic 'storm' of Oct. 12.

Meteor Shower of Giacobini's Comet.-Mr. W. F. Denning writes that "two observers watched the sky from Bristol on Oct. 8, 9, and 10 from about 6.30 P.M. to 9.30 P.M., though the moon was near the full and some fog prevailed. The object was to

No. 3025, VoL. 120]

\section{ical Column.}

observe a few meteors from Giacobini's comet, the orbit of which lies near the earth's path on Oct. 9-10. It may be remembered that last year a definite shower was witnessed on Oct. 9 with a radiant agreeing with that computed for the comet named. Owing to the unfavourable conditions, few meteors were noticed this year, but on Oct. 8 about eight were seen and ten on Oct. 9. A fine flashing meteor was seen on Oct. 8 at 7.56 P.м. in the south-west, but it could have had no association with Giacobini's comet. On Oct. 9 seven meteors were recorded, which showed diffuse radiation from $260^{\circ}+53^{\circ}$, and there is little doubt that this shower represented a return of the display of 1926 , as the date agrees and the position of radiation, in the head of Draco, nearly coincides. No doubt the display would have been more abundant and the individual objects more brilliant but for the fog and moonlight which madguthe circumstances extremely unfavourable."

Pнотомetry ofv Tun Moon's SURFACE.-Astr. Nach. No. 55pt connains observations of the albedo of various resions of the moon, made by A. Markov at Pulkovo. The observations were photographic on Agfa plates. Photographs of stars and of a standard lamp were taken for comparison. Aristarchus is the region of highest albedo, the value being $0 \cdot 37$, Tycho and Proclus eoming next. It will be noticed that the value is far below that for snow, which some had suggested as possibly present on the brighter regions. The darkest regions are Schickard and Grimaldi with values 0.09 and 0.07 . The mean albedo of the disc is about $0 \cdot 16$, in good agreement with former determinations. 